\title{
Kuşakların Hemşirelikte Yönetim ve Eğitim Pratikleri Açısından İncelenmesi
}

\author{
Ebru SEVINÇ*, Derya KAVGAOĞLU**
}

$\ddot{O} \mathbf{z}$

Sağlıkta yönetim ve eğitim çabalarından etkili ve verimli sonuçlar alınabilmesi için üzerinde durulması gereken önemli bir konu, hedef kitlenin bireysel farklılıklarının anlaşılmasıdır. Kuşak olgusu bu bireysel farklılıkların açıklanmasında, yönetsel ve eğitsel olarak etkileşim kurulacak kitlenin tanınmasında ve beklentilerinin anlaşılmasında yol gösterici bir faktör olarak değerlendirilebilir. Yaklaşık olarak yirmi beş, otuz yıllık yaş kümelerini oluşturan ve aynı çağın şartlarına maruz kaldığı için benzer davranış örüntülerine sahip bireyler öbeği olarak tanımlanan kuşak literatürde beş farklı formda yer almaktadır. Bunlar: Sessiz kuşak, bebek patlaması kuşağı, X kuşağı, Y kuşağı ve Z kuşağıdır. Sessiz kuşak hemşirelerinin yaşam boyu tek bir kurumda çok sıkı çalışma olanağına sahip olmaları iş doyumuna ulaşmaları için yeterlidir. Bebek patlaması kuşağı hemşirelerinin işleri yaşamlarının çok önemli bir bölümünü oluşturur ve iş doyum düzeyleri yüksektir. $\mathrm{X}$ kuşağı hemşireleri iş hayatında kendilerini zorlu, iyimser ve kendine güvenen bireyler olarak tanımlamaktadır. Bu üç kuşağı eğitsel pratikler açısından esasici ve gelenekçi stillerle, yönetsel açıdan duygusal bağllığı pekiştirecek pratiklerle desteklemek mümkündür. Y kuşağı hemşireleri gruplar halinde çalışmakta ve teknolojiyi çok iyi kullanmaktadır. Z kuşağının ilk üyeleri önümüzdeki seneler içerisinde çalışma hayatına girmiş olacağından bu kuşakla ilgili çok fazla araştırma bulunmamakla birlikte teknoloji odaklı ve bağımsız çalışma eğilimi içinde olmaları beklenmektedir. Bu iki kuşağı eğitsel açıdan geleneksel öğretimden ziyade öğrenen merkezli ve teknoloji tabanlı etkinliklerle; yönetsel açıdan normatif bağlılığı duygusal bağlılığa dönüştürecek pratiklerle desteklemek mümkündür. Bu çalışmada,

\section{Derleme Makale (Review Article)}

Geliş / Received: 02.10.2019 \& Kabul / Accepted: 22.10.2019

* Öğ. Gör., İstanbul Gelişim Üniversitesi, Sağlık Bilimleri Yüksekokulu, İstanbul, Türkiye, E-posta: esevinc@gelisim.edu.tr ORCID ID https://orcid.org/oooo-0003-3553-5825

** Dr. Öğ. Üyesi, İstanbul Gelişim Üniversitesi, Sağlık Bilimleri Yüksekokulu, Sosyal Hizmet Bölümü, İstanbul, Türkiye, E-posta: dkavgaoglu@gelisim.edu.tr

ORCID ID https://orcid.org/o0o0-0001-5926-3081 
hemşireliğin kuşaklar arası bireysel, mesleki, teknolojik, örgütsel ve eğitsel olarak farklılıklarının literatür bilgileri doğrultusunda incelenmesi amaçlanmaktadır.

Anahtar Kelimeler: Hemşire, kuşaklar, yönetim, eğitim, kuşaklar arası farklılıklar.

Examination of Generations in Terms of Nursing Management and Training Practice

\begin{abstract}
Understanding the individual differences of the target audience is an important issue that needs to be addressed to obtain effective and efficient results from health management and education efforts. The phenomenon of generation can be considered as a guiding factor in explaining these individual differences, recognizing the audience to be interacted managerially and educationally and understanding their expectations. The generation, which is composed of approximate twenty-five, thirty-year age clusters and is defined as a group of individuals with similar behaviour patterns because of being exposed to the conditions of the same age, has five different forms of expression in the literature. These are; Silent Generation, Baby Boom Generation, Generation X, Generation Y, Generation Z. It is enough for the Silent Generation nurses to have the opportunity to work very hard in a single institution throughout their life. The work of Baby Boom Generation nurses is a very important part of their lives and their job satisfaction levels are high. Generation X nurses identify themselves as challenging, optimistic and confident individuals in their work life. It is possible to support these three generations with fundamentalist and traditional styles in terms of educational practices and with practices that will reinforce managerial emotional commitment. Generation Y nurses work in groups and use technology very well. Since the first members of Generation $\mathrm{Z}$ have entered the work life in the coming years, there is not much research about this generation. However, they are expected to be technology-oriented and independent. These two generations are learner-centered and technology-based activities rather than traditional teaching; it is possible to support managerial normative commitment with practices that will transform it into an emotional commitment. In this study, it is aimed to examine the differences of nursing between generations as individual, professional, technological, organizational and educational in line with the literature.
\end{abstract}

Keywords: Nurse, generations, management, education, differences between generations.

\title{
Giriş
}

Değişen ekonomik, teknolojik, sosyolojik, kültürel ve politik zemin beraberinde toplumları ve bireyleri de etkileyerek farklılaştırmaktadır. Bu durum, farklı zaman 
dilimlerinde benzer biliş, değer, tutum, inanç ve davranışlarla sembolize, farklı topluluklar oluşmasına neden olmaktadır ${ }^{1-5}$. Bu durumun Strauss ve Howe tarafından ortaya atılan kuşak teorisiyle izahı şu şekilde mümkündür; bireyler yaşadıkları döneme denk gelen savaş, ekonomik kriz, teknolojik gelişim, toplumsal değişim gibi olaylardan kısa ve uzun vadede etkilenirler. Bu bağlamda aynı yaş grubu bireyler benzer değer ve davranış örüntülerine sahipken farklı yaş grupları farklı değer ve davranış örüntüleri sergilerler. Kuşak ya da nesil olarak ifade edilen bu toplulukların tanımlanması ülkeden ülkeye değişiklik göstermekte, kesin çizgilerle ayrımı her zaman doğru veya mümkün olmamaktadır. Bununla birlikte, ortalama yirmi beş ila otuz yıllık periyotlarla yerlerini yeni topluluklara bıraktıkları kabul edilmektedir²,6-8.

Sağlık yöneticilerinin ve eğitimcilerinin çabalarından etkili ve verimli sonuçlar alınabilmesi için üzerinde durulması gereken önemli yönetsel ve eğitsel konuların başında etkileşim kurulacak bu farklı kuşakların tanınması ve beklentilerinin anlaşılması yer almaktadır. Bu sayede, sağlı işletmelerinde hedef kitlenin vizyonuna yönelik idaresi ve gelişimi için daha hızlı ve etkili sonuç almak mümkün olabilecektir. Literatürde, sessiz kuşak, bebek patlaması kuşağı, X kuşağı, Y kuşağı ve Z kuşağı olmak üzere beş farklı kuşağın varlığından söz edilmektedir.

Türkiye'nin \%7'sini oluşturan sessiz kuşak, 1925-1945 yılları arasında varlık bulmuş uyumlu bir kuşaktır ${ }^{9}$. Bu tarihler, II. Dünya Savaşı'nın çıktı̆̆ı dönemi işaret etmektedir ve bu dönemde dünyaya gelen popülasyon savaş acılarına en fazla maruz kalan popülasyon olarak düşünülebilir. Kuşağın kültürel öğeleri içinde geniş aileler, yerel sosyal gruplar ve yoğun komşuluk ilişkileri yer alır. Temel değerleri arasında otoriteye saygı, sadakat, çok çalışma ve toplumsal değerlere adanmışlık yer almaktadır. Bu kuşak maruz kaldığı yoksulluklar nedeniyle tutumludur, temkinlidir, sosyal problemlere duyarlı ve gelenekseldir. Yaşamak için çalışmak felsefesini benimseyen bu kuşağın temel ihtiyacı güvendir7,10. Yönetsel ve eğitsel pratikler açısından değerlendirildiğinde bu kuşağın doğrudan, net ve organize olmuş bilgileri almayı, güven duygusu temin ettiğinde aynı işte uzun soluklu çalışmayı tercih ettiğini söylemek mümkündür². Cumhuriyetin bu ilk kuşağı Türkiye'de tek partili hayattan çok partili hayata geçmiş, ihtilaller görmüş ve radyonun altın çă̆ını yaşadığı döneme tanıklık etmiştir. Bununla birlikte bugün bu kuşağa ait kişilerin \%95’i emekli olmuştur. 
Türkiye'nin \%19'unu oluşturan bebek patlaması kuşağı, 1946-1964 yılları arasında varlık bulmuş kuralcı bir kuşaktır9. Bu tarihler II. Dünya Savaşı sonrası artan refah dönemine denk gelmektedir. Bu dönemde doğurganlık oranında önemli bir artış olmuş yetmiş altı milyon insan dünyaya gelmiştir. Sayıca fazla olan bu kuşak bu sayede toplumu yeniden şekillendirmiştir. 68 Kuşağı olarak tanımlanan ve bir önceki kuşaktan aydınlanma devrimini talep edip insan haklarına odaklanan kuşaktır. Geleneksel olarak tanımlanan bu kuşak çalışmak için yaşamak felsefesini benimsemiştir7. Yönetsel ve eğitsel pratikler açısından değerlendirildiğinde bu kuşağın, yüksek sadakat ve kanaatkâr tutumla karakterize olduğunu, aynı işte uzun soluklu çalışmayı tercih ettiğini, duygusal ve otoriteye bağlı olduğunu gerektiği zaman teknolojiyi kullandığını söylemek mümkündür. Bu kuşak ayrıca yetki duygusu ve işkolik olma gibi bazı olumsuz özelliklerle de anılmaktadır². Paraya önem verip kalite standartlarını da yüksek tutan bu kuşak eğlence ve lüks sayılabilecek harcamalarıyla turizm sektörünün gelişmesine de yardımcı olmuştur. İdealist, rekabetçi ve eğitime önem veren bir anlayışa sahiptir. Petrol krizlerini, sağ-sol çatışmaları görmüş, sinemaya gitmiş ve televizyon (TV) seyretmişlerdir. Teknolojinin hızlı gelişimine tanık etmişlerdir. 2019 yılı itibariyle 55-73 yaşları arasında olan bu kuşak emeklilik sonrasında da çalışmayı sürdürebilmektedir.

Türkiye'nin \%22'sini oluşturan X kuşağı, 1965-1979 yılları arasında varlık bulmuştur. Bebek patlaması kuşağının refah içinde yaşamasının faturası ile zaman zaman yüz yüze gelen bu kuşak devam eden süreçte devletlerin maliyetleri karşılayamaması neticesinde yaşanan çeşitli krizlerden etkilenmiştir. Türkiye'de 1980 ihtilalini görüp, Turgut Özal dönemini yaşayan kuşaktır. Kitlelerce kabul edilen ilk global kuşak olup, müzik televizyon kanalı (MTV) kuşağı olarak da anılmaktadırlar. Kuvvetli bir ideolojileri olmayıp tek başına ayakta durabilmeyi ve liderliği önemsemişlerdir. Geleceğe yönelik olarak duydukları sürekli kaygı onları çok çalışmaya, çok kazanmaya ve kariyer yapmaya yönlendirmiştir7. Yönetsel ve eğitsel pratikler açısından değerlendirildiğinde bu kuşağın rekabetçi, teknoloji ve bilgi ile barışık, girişimci, amaç odaklı ve bağımsız oldukları söylenebilir. İş hayatında çalıştıkları kuruma olan bağlılıkları ve uzun süre aynı yerde çalışmalarıyla ve kariyer düşkünlükleriyle bilinmektedirler ${ }^{2,7,9}$. Kuşağın yönetsel ve eğitsel pratikler açısından dikkate değer diğer bazı özellikleri ise şöyle sıralanabilir; saygın bir statü sahibi olmayı, para ve bireysel sosyalleşmeyi önemserler. Bir önceki kuşağa oranla daha fazla eğitim almış ve daha geç evlenmişlerdir. Okumak 
ve fikir paylaşımı bu kuşakta yerini bol bol film, video ve TV seyretmeye bırakmıştır. X kuşağı insanları genellikle tepkisiz olmakla birlikte global, toplumsal sorunlara duyarlı ve cinsiyet eşitliğine önem verir. Kendi sorunlarını kendi çözmeye alışmış ve bu nedenle de kendine güveni yüksek olan bir nesil olmuştur. 2019 İtibariyle 39-54 yaş aralığına mensup olan bu bireyler iş yaşamında iyimserlik, güvenirlilik, sağlığa önem verme, dinamizm, çalışkanlık ve bağlılık gibi değerleri temsil edebilir7.

Türkiye'nin \%35’ini oluşturan Y kuşağı, 1980-1999 yılları arasındaki yaratıcı bir

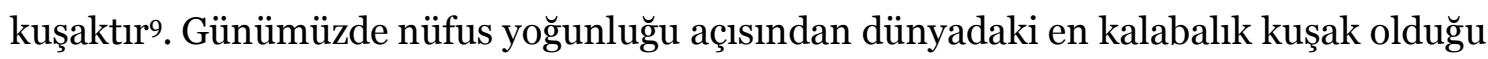
kabul edilen bu kuşağın Türkiye'deki en belirgin özelliği teknolojinin getirdiği bir eğilim olarak global değerlere daha yakın oluşudur. Yönetsel ve eğitsel pratikler açısından değerlendirildiğinde bu kuşağın diğer kuşaklardan farklı olarak dijital medyanın cazibesiyle büyüyen ilk kuşak olma özelliğine sahiptir. Bu kuşak aynı zamanda internet kuşağı olarak da anılmaktadır. Yüksek adaptasyon gücüne sahiptir ve çoklu görevler yapabilmektedir². Teknolojiyle bütünleşen bu kuşak, istekleri, motivasyonları ve değerleri ile çok farklı bir profil çizmiştir. Teknolojiye bağımlı olmakla birlikte değişime açık, zor tatmin olan, özgüveni yüksek, emir almayı ve hiyerarşik düzenleri sevmeyen bununla birlikte hırslı, sabırsız ve sadakatsiz bir nesli temsil ederler. Gelişmiş toplumlara ve metropol şehirlerine bakıldığında, Y Kuşağını çoğunlukla çalışan veya çalışmış annelerin yetiştirdiği bununla birlikte boşanma oranlarının onların gençliğinde hiç olmadığı kadar yüksek seviyelere ulaştığı görülmüştür. Bu durum neticesinde kendi kendilerine yetmeyi ama aynı zamanda talep etmeyi öğrenmek zorunda kalan girişimci bir nesil olarak yetişmişlerdir. Sıra dışı, realist, sorgulayıcı ve talep kâr bir bakış açısına sahip olan bu kuşağın ebeveynlerinin diğer kuşaklara oranla bireysel varoluşu pekiştirecek bir yetiştirme tarzı benimsediği de söylenebilir. Bu durum Y kuşağının sağlıklı iş-yaşam dengesine ulaşma eğiliminde bir belirleyici olmuştur. Bireyselliklerine ve özgürlüklerine düşkün olan bu kuşak önceki kuşaklardan farklı olarak lisansüstü eğitime daha çok rağbet göstermiş; yüksek lisansı yapılması gereken; doktorayı ise yapılması halinde kolaylık sağlayıcı bir diploma olarak görmüştür. Kuşağın önemli bir özelliği akran gruplarının onayına ilişkin hassasiyetleridir. Tercihlerini yaparken veya kararlarını verirken işte, sosyal medyada veya okulda dahil olduğu grupların karar ve tercihlerini referans alarak ilerlerler ${ }^{7,11}$. 
Türkiye'nin \%17'sini oluşturan Z kuşağı, 2000-2010 yılları arasında varlık bulmuş bir kuşaktır7 . Bu dijital kuşağı aşırı bireyselleşme sonucu yalnızlık yaşayacaklarından dolayı "Yeni Sessiz Kuşak” olarak da tanımlamaktadır. Bu kuşağın sorgulayan, kendi kendine yetebilen ve olgun bir kuşak olması beklenmektedir. X kuşağının özenle yetiştirdiği ve çalışan anne-babaların çocukları olan Z kuşağı sokakta oynama zevkini en az yaşayan ama ailesinin dikkat ve ilgisini de en çok gören nesildir. Doğdukları andan itibaren yüksek teknoloji ürünlerini kullanmaya başlayan bu kuşak, yeryüzünün en bağlantılı “connected” ve dolayısıyla işbirlikçi, açık fikirli ve yaratıcı kuşağıdır. Şehirlerde ve gelişmiş toplumlarda önceki kuşaklara göre daha fazla yaşlı ailelere sahiptir. Yaşça daha büyük öğretmenler tarafından eğitilmiştir. Bir tıklamayla istediği bilgiye ulaşabilen bu kuşak daha erken yaşta eğitilebilmekle birlikte, ileri eğitimlerinde de eğitim metotları açısından çok yenilikçi yaklaşımlara ihtiyaç duymaktadır. Yönetsel ve eğitsel pratikler açısından değerlendirildiğinde derin duygusallığı içeren bir kuşak olup, internet kuşağı olarak da adlandırılırlar. Yeni teknolojik olanaklarla iletişim ve ulaşım kolaylıkları, uzakta olsalar bile cebe sığan teknolojik araçlarla her an birbirleriyle bağlantı kurabilmektedirler. Insanlık tarihinin el, göz, kulak, motor beceri senkronizasyonu en yüksek nesli olarak tanımlanmaktadırlar7,9.

Strauss ve Howe'un Z kuşağı için yaptığı "Yeni Sessiz Kuşak” tanımı ise aslında rastlantı değildir. Zira bu tanım Strauss ve Howe'un 1997 yllında "The Fourth Turning" ismiyle yayınladıkları teorinin önemli bir parçasını oluşturmaktadır. Buna göre nesiller seksen yıllık bir döngü içinde yinelenen dört temel periyotla devinim gösterir. Döngü krizle başlar. Toplum, düzeni ve yapıyı etkileyen bir durum nedeniyle, durmak ve sorunu çözmek zorunda kalır. Bu dönemde doğan kuşaklar Sessiz kuşaktır. Bu dönemin ardından toparlanma dönemi gelir. Büyük hayaller kurulur ve yeni vizyonlar oluşturulur. Patlamanın yaşandığı dönem ise bu dönemdir. Ancak ideal dünya düzeni sürdürülebilir olmaması, büyük vizyonların bazılarının hayal kırıklı̆̆ına dönüşmesi nedeniyle toplum kendini daha gerçekçi bu yeni duruma adapte eder. Bu dönemi yeni liderlerin, yeni oluşumların ortaya çıktığı, genç kuşakların desteklendiği dönem takip eder. Ama toplumun kendine döndüğü bu yapıcı dönem korunamaz. Kriz ortaya çıar ve döngü yeniden başlar7. Farklı olarak, Z kuşağını takip eden ve 2010 yılı sonrasında dünyaya gelen kuşağı Alfa Kuşağı olarak tanımlamakta ve bu kuşağı otonom robotlarla arkadaşlık kuracak dijital çă̆ çocukları olacaklarını ifade etmektedir. Buna göre 
kuşağın temel karakteristiğini ise konformizm, benmerkezcilik, girişimcilik, acelecilik, sabırsızlık gibi kavramlarla açıklanmaktadır ${ }^{12}$.

Literatürde yer alan bu beş kuşağl, hemşirelerin eğitim ve gelişime yönelik olarak verecekleri muhtemel tepkiler ve tarihsel perspektif içinde eğitim akımları açısından değerlendirdiğimizde şunları söylemek mümkündür; eğitim akımları iki farklı grubun sesiyle açıklanabilir. Bu gruplar gelenekçiler ve yenilikçilerdir. Gelenekçiler mevcut bilgi ve değerleri muhafazaya önem verirken bunu öğretimle, disiplinle sağlamaya çalışan gruptur. Karşısında yer alan yenilikçiler ise daha ileriye bakıp geleceği inşaya önem veren, bunu da öğrenmeyle ve tecrübeyle elde etmeye çalışan gruptur ${ }^{13}$.

Geleneksel müfredat tasarımında bilgiye akademik disiplin kurallarıyla ulaşılır. Bilginin alıcısı olan bütün bireyler benzer şekilde öğrenir. Öğrenen merkezli müfredat ise öğrenenleri öğrenme probleminin içine çeker, bir miktar kontrol yetkisi verir, sınıfı herkesin öğrenme gündemini paylaştığı bir topluluk olarak kabul ederek iş birliğini teşvik eder. Öğrenen merkezli eğitim, değişen topluma hızlı adapte olan otonom ve yaratıcı bireyler yetiştirir, günümüz işgücünün kesinlikle temel kabiliyetleri olarak düşünülen inovatif düşünmeyi ve yaratıcılığı besler ${ }^{14}$. Eğitim akımlarını etkileyen eğitim felsefeleri kesin çizgilerle birbirlerinden ayrılmamakla birlikte gelenekçi yaklaşımları idealist ve realist felsefeye, yenilikçi yaklaşımları ağırlıklı olarak pragmatizmle açıklamak mümkündür ${ }^{13,15}$. Cumhuriyet döneminde eğitim sisteminin, genelde pragmatik felsefeye ve onun bir uzantısı olan ilerlemecilik akımına dayandığını ifade eder. Ancak anayasalar, yasalar ve hükümet programlarında ilerlemecilik akımı kuramsal olarak savunulurken, uygulamaların bu doğrultuda olmadığını vurgular. Ona göre, genelde her dereceli okulda ilerlemecilik değil, esasicilik ve daimicilik temele alınmış ve uygulanmıştır. Başka bir deyişle, öğrenci değil, öğretmen ve konular merkeze alınmış, bilimsel yöntemi kullanan, özgür ve esnek düşünen, demokratik, laik, sosyal adaletçi, sevgi ve saygıya değer veren insan yerine; öğretmenin söylediklerini, kitapların yazdıklarını ezberleyen, skolastik düşünce sistemi ile donanmış kişiler yetiştirilmiştir. Ayrıca sistem kuramsal olarak her kişinin ilgi, yetenek ve istekleri doğrultusunda eğitilmesini savunurken, uygulamada bu özellikler genelde dikkate alınmamış, tersine rekabetçi bir yaklaşım işe koşulmuştur. Kısaca Cumhuriyet döneminde Türk eğitim sistemi; tasarıda pragmatizme göre düzenlenmiş, fakat uygulamada realist ve idealist felsefelere dayanan esasici ve daimici eğitim akımlarını 
kullanmıştır. Cumhuriyet dönemini takiben 1940 yılında açılan Köy Enstitüleri ilerlemeci bir felsefeyi beraberinde getirse de 1954'te siyasi kayglarla kapatılmıştır. Takip eden dönemde konu alanı odaklı 1948 programı, bunu eleştirerek öğrenen merkezli pratiklere odaklanmaya çalışan ancak sürekliliği sağlanamayan 1962 program taslağı ve 1968 programı, 1980-1990 yılları arasındaki kredili sistem ve standartlaşma çalışmaları, 1994 Müfredat Laboratuvar Okulları, Z kuşağı öncesi tüm kuşakların yetiştiği geleneksel esasici eğitim felsefesi zeminini oluşturur. Teknolojik gelişmeler dikkate alındığında, Y kuşağının öğrenme öğretme ortamlarındaki dijitalleşme dolayısıyla esasici zeminden kısmen daha az etkilendiğini söylemek mümkün olabiliriri, bilim ve teknoloji alanındaki ilerlemelerle ortaya çıkan yeni bakış açılarının ülkelerin eğitim felsefeleri üzerinde doğrudan etkili olduğunu ifade eder. 200o’li yllarda Amerika, İngiltere, Kanada, Avustralya, Avusturya, İsrail ve Yeni Zelanda yapılandırmacı anlayış doğrultusunda eğitimlerini ve öğretim programlarını yeniden yapılandırmışlar; Türkiye de aynı çaba içine girerek 2005-2006 eğitim öğretim yılından itibaren yapılandırmacı öğrenme yaklaşımını uygulamaya koymuştur. Yapılandırmacı yaklaşım, geleneksel yapıda yetişmiş öğretmenlerle kısıtlı olsa da felsefesi itibarıyla fikren ve fiilen yapıcı ve güçlü yeni kuşaklar yetişmesini sağlamada etkili bir yöntem olarak görülmüştür. Y kuşağının kısmen etkilendiği, Z kuşağının ise yetiştiği eğitim zemini bu ilerlemeci ve öğrenen merkezli zemindir. Hemşire eğitimde de temel stratejiler, tüm kuşakların maruz kaldıkları eğitim-öğretim pratiklerinin, onların öğrenme stilleri üzerinde etkili olmuştur varsayımından hareketle organize edilebilir. Buna göre, geleneksel metotla yetişmiş hemşirelerin eğitmen merkezli, tümdengelimi esas alan, kısa zamanda çok fazla bilginin örgütlenmiş, ardışık, sıralı bir şekilde verildiği sunum stratejisiyle öğrenmesi daha hızlı ve kalıcı olabilir. Bu kuşağın hemşireleri için rekabete dayalı, sonuç odaklı, iyi yapılandırılmış, soyut ve sembolik öğrenmenin hakim olduğu eğitsel süreçler yapılandırılabilir. Yenilikçi eğitim yaklaşımlarına maruz kalarak yetişmiş hemşireler için ise öğrenen merkezli ve keşfederek öğrenmeye dayalı, yaşantısal, bireysel, esnek, yorumlayıcı, problem merkezli öğretim tasarımları tercih edilebilir. Kılavuzlanmış buluş ve araştırma stratejileri bu kuşağın hemşirelerinde hızlı ve kalıcı öğrenmeler için etkili bir strateji olarak düşünülebilirir,18. Bununla birlikte gelenekçi grupta yenilikçi, yenilikçi grupta gelenekçi teknikleri denemek de mümkündür. 
Literatürde yer alan bu beş kuşağın yönetimsel açıdan dikkate alınmaya değer ayırt edici hemşirelik özellikleri vardır. Sessiz kuşak hemşireleri çok sıkı çalışmakta, bu sıkı çalışmalarının sonucunda ödüllendirileceklerine inanmaktadır. Yaşam boyu tek bir kurumda çalışmaya devam ederek işlerini iyi yapmak onların doyuma ulaşması için yeterli olmaktadır. Bebek patlaması kuşağı hemşirelerinin iş doyumu düzeylerinin yüksek olduğu belirtilmektedir. İşlerini yaşamlarında çok önemli bir yere koyarken, günde 12-14 saat çalışabilmektedirler ${ }^{19}$, X kuşağ güç’tür. Bu kuşak hemşireleri kendilerini zorlu, iyimser ve kendine güvenen bireyler olarak tanımlamaktadır²o. Kendi zamanlarını nasıl yöneteceklerini ve sınırlarını bilmektedirler. $\mathrm{Bu}$ kuşak hemşireleri bir denetim olmadan işlerini tamamlamaktadırlar²1. Y kuşağı hemşireleri işte takımlar halinde çalışmayı ve işlerinin büyük bir amaca katkıda bulunmasını tercih etmektedir ${ }^{20}$. Y kuşağı hemşirelerinin çalışma programı, uyum sağlama, performans, öğrenme tarzı, teknoloji bilgisi, öncelikler ve mesleki imaj gibi konularda daha eski kuşaktaki hemşireler için tehdit oluşturduğu ifade edilmektedir ${ }^{21}$. Z kuşağının ilk üyeleri önümüzdeki beş sene içinde çalışma hayatına girmiş olacaklardır. Dolayısıyla literatürde, bu kuşakla ilgili çok fazla araştırma bulunmamaktadır².

Kuşakların çalışma yaşamında birbirinden farklı tutum ve davranışlar sergilemeleri, kuşak bazlı yönetim stratejileri üzerinde düşünmeyi gerekli kılmaktadır ${ }^{1,22}$. Nitekim kuşakların kişilik özellikleri, yönetim algısı, yönetimle ilişkisi ve liderlik tarzı ile ilgili beklentilerin saptanması yönetim çalışmaları açısından önemlidir ${ }^{10}$. Yapılan çalışmalarda kuşaklar arasında yönetim tarzları ile ilgili farklı beklentiler saptanmıştır. $\mathrm{X}$ kuşağı ve kısmen önceki kuşaklar; kendine güvenen, sorumluluğun kendisinde olması kaidesiyle insiyatif kullanmak isteyen, otoriteye saygılı, emir almaya yatkın, yönetim tarzı olarak da otoriter bir yönetime yatkın olan ancak yeri geldiğinde bunu demokratik katılımla pekiştirmek isteyen kuşaklardır. Y kuşağı; kendine her açıdan güvenen, takım çalışmasına yatkın olan yönetim tarzı olarak da otoriteyi sevmeyen, emir almaktan hoşlanmayan, demokratik katılımcı bir tarzı benimseyen kuşaktır. Z kuşağl; iş hayatında teknolojiyi vazgeçilmez olarak gören, yeniliklerin iş yaşamına entegre edilmesini isteyen, çabuk öğrenen, kolay uyum sağlayan, yönetim tarzı olarak otoriter yönetim ve yöneticiden hoşlanmayan, demokratik ve lider yapıda yönetimi benimseyen bir kuşak olarak tanımlanmaktadır ${ }^{7,23}$. 
Yöneticilerin kuşakların özellikleri hakkında bilgi sahibi olmaları, her kuşağın farklı özelliklerini, güçlü ve gelişime açık yönlerini tanımaları bu anlamda gereksinimlere cevap veren bir yönetim şekli benimsemeleri, çalışanların verimlilikleri ve motivasyonları üzerinde doğrudan etkilidir ${ }^{1}$. Buraya kadar ifade edilenler ışı̆̆ında, farklı kuşakları gerek bir arada tutabilmek gerekse eğitim ve gelişimlerine destek olarak onlardan daha iyi verim alabilmek üzere dikkat edilebilecek hususlar şu şekilde özetlenebilir; kuşak farlılıklarını tanıyabilmek bu kapsamda bireysel farklılıkları dikkate alan liderlik ve yönetim stillerini kullanabilmek, bürokrasiyi azaltarak, informal iletişime önem vermek, çalışanları yapılan işlere ve alınacak kararlara dahil eden demokratik bir yönetim tarzı benimsemek, "ben” odağı yükselen çalışanların bireyselleşen taleplerine karşılık verecek esnek sistemler kullanmak, teknoloji destekli uygulamalarla çeşitlendirilmiş öğrenme ve gelişim firsatları yaratmak, yetenek yönetimi sistemiyle terfi ve kariyer basamakları oluşturmak, koçluk/mentorlük programları düzenlemek, tüm kuşakların etkileşim düzeylerini artıracak sosyal iletişim platformları oluşturmak, farklı fikirlerin tartışılacağı fikir atölyeleri, problemlere kolektif bir anlayışla çözüm getirecek çalıştaylar düzenlemek, tüm kuşakların bir arada olabileceği ortak aktivitelerle sosyal etkileşimi artırmak, kişisel ve mesleki yetkinlikleri geliştirecek eğitim programları organize etmek, takım çalışmalarını teşvik etmek ve en önemlisi etik kurallar çerçevesinde tarafsız olabilmektiri,22,24. Bu hususlara dikkat ediyor olmak aynı zamanda bu kuşakların kurumsal bağlılığını artırma noktasında da önem arz etmektedir.

Kurumsal bağlılık konusunda yapılan araştırmalar bağlılık türleri konusunda farklı yaklaşımlar ileri sürmüşlerdir. Meyer ve Allen 1984'te bu yaklaşımlardan ilkini, kuruma karşı güçlü duygusal bağlılığı ifade eden, duygusal bağlılık, ikincisini, çalışanların ayrılmanın maliyeti üzerine inşa ettiği bağlılık türü olan devam bağlılığı şeklinde isimlendirmiş; 1990'da üçüncü bir bileşen olarak yapılacak en doğru şeyin bu olduğu inancından kaynaklanan, kurumda kalma zorunluluğu hissi anlamına gelen normatif bağlılı̆̆ı eklemişlerdir. Meyer ve Allen literatürdeki tüm tanımların üç genel temadan birini yansıttığını, bu üç bileşenin de birbiriyle ilişkili olduğunu vurgulamışlardır²5. Kuşakların temel değerleri dikkate alındığında Y kuşağı öncesinde otoriteye saygı, sadakat ve iş odaklılık gibi motifler daha baskın olduğu için gerekli koşullar sağlandığında bu kuşaktaki duygusal bağlılığın daha çabuk ve kalıcı olacak şekilde 
sağlanabileceği söylenebilir. Bununla birlikte davranışlarında daha konformist, özgür ve bireyci motifleri taşıyan X kuşağı sonrası kuşaklarda daha ziyade normatif bağlılı̆̆ın baskın olacağı düşünülebilir.

\section{Sonuç ve Öneriler}

Günümüzde hastanelerin karmaşık yapılarının yanı sıra farklı kuşakların bir arada çalışması nedeniyle ortaya çıkan sorun ve çatışmalar muhtelif çalışmalarla ortaya konulmaktadır.

Yönetici hemşirelerin, kuşak farlılıklarını tanıması ve anlaması, hedef kitlenin yönetim ve eğitim problemlerini çözmesinde kendisine yardımcı olabilecektir. Hemşirelikte kuşak farklılıklarının yönetimi ve eğitimine ilişkin sınırlı sayıda araştırma vardır ve bunlar da kamu kurumlarında ve büyük illerde yapılmıştır. Bu araştırmalarda iş doyum düzeyi, işe adanmışlık, örgütsel adalet algısı, bireycilik, otonomi, takım çalışması, öğrenme tarzı, teknolojiye yatkınlık ve internet kullanım alışkanlıkları, siyasal yaklaşım, başarı motivasyonu, kariyer beklentisi gibi faktörler kuşak temelli incelenmiştir ${ }^{2,6,19,21,22,26-34}$

Farklı kuşaklar farklı değer sistemlerine sahip olduklarından kurumsal yapı içinde de yönetilebilirlikleri, bağlılıkları, eğitim ve gelişim faaliyetlerine katılımları açısından homojen bir yapı göstermemektedirler. Sadece kuşak farklarının tespitine odaklanmış olmaları ve sayıca az olmaları yapılan araştırmaların kısıtlılığı olarak değerlendirilebilir. Bu derlemede farklı olarak kuşak farklarını tanımlamanın ötesinde, kuşakları doğru yönetmek üzere yönetsel ve eğitsel stratejilerin nasıl kullanılabileceği problemi teorik zeminde tartışılmıştır. Bundan sonra yapılacak araştırmalarda kuşak farklılıklarının yönetimine ilişkin kalitatif ve kantitatif çalışmalar yapılabilir. Bununla birlikte yapılacak araştırmaların sayıca artırılması istisnaların yakalanması ve genellemelerin genel geçerliğinin tartışılması açısından önem arz etmektedir.

\section{KAYNAKLAR}

1. Ayhün ES. Kuşaklar arasındaki farklılıklar ve örgütsel yansımaları. Ekonomi ve Yönetim Araştırmalar Dergisi. 2013;2(1):93-112. 
2. Adıgüzel O, Batur H, Ekşil N. Kuşakların değişen yüzü ve y kuşağı ile ortaya çıkan yeni çalışma tarzı. mobil yakalılar. Süleyman Demirel Üniversitesi Sosyal Bilimler Enstitüsü Dergisi. 2014;1(19):165-182.

3. Mannheim K. The problem of generations' in Mannheim, K. Essays on the Sociology of Knowledge (First Published 1923). London: RKP. 1952.

4. McCourt DM. The Problem of Generations Revisited: Karl Mannheim and the Sociology of Knowledge in International Relations. In: Steele B.J., Acuff J.M. (eds) Theory and Application of the "Generation" in International Relations and Politics. Palgrave Macmillan, New York. 2012.

5. Mücevher M, Erdem R. X kuşağı akademisyenler ile Y kuşağı öğrencilerin birbirlerine karşı algıları. Süleyman Demirel Üniversitesi Vizyoner Dergisi. 2018;9(22):60-74.

6. Aydın Ç, Başol O. X ve Y Kuşağı: Çalışmanın anlamında bir değişme var mı? Electronic Journal of Vocational Colleges-December.2014.

7. Sanje G. Türk Telekom Yönetici Gelişim Programı: Nesiller ve Dijital Dünya Semineri 2013; Bilgi Üniversitesi Santral İstanbul Kampüsü.

8. TDK, Büyük Türkçe Sözlük. Kuşak ne demek? https://tdk.gov.tr/ Erişim tarihi: 17 Temmuz 2019.

9. Yılmaz K. Hemşireliği gelecekte nasıl bir nesil bekliyor? Acıbadem Hemşirelik edergisi. 2013;62:1-7.

10. Demirkaya H, Akdemir A, Karaman E, Atan Ö. Kuşakların yönetim politikası beklentilerinin araştırılması. Isşletme Araştırmaları Dergisi. 2015;7(1):186-204.

11. Ağırdır B. Y Kuşağı İnovasyon Araştırması. Deloitte Eğitim Vakfı. Millward Brown.http://www.deloitteegitimvakfi.org.tr/UserFiles/Documents/Y Kusagi In ovasyon.pdf Erişim tarihi: 10 Haziran 2019.

12. Tarhan N. Dijital Çağın Çocukları Alfa Kuşağı. TRT Vizyon Dergisi. 2019;353.

13. Doll RC. Curriculum Improvement Decision Making and Process. 8.th ed. Boston: Allyn and Bacon Publishing. 1992. 
14. Kavgaoğlu D, Elkin N. Hemşirelik bölümü kişilerarası ilişkiler ve terapötik iletişim dersi öğretim programının değerlendirilmesi. İstanbul Gelişim Üniversitesi Sağlık Bilimleri Dergisi. 2019;7:670-696.

15. Gözütok Dilek F. Türkiye'de program geliştirme çalışmaları. Milli Ĕ̆itim Dergisi. 2003;160.

16. Taş AM. Newton ve Kuantum Felsefelerinin Eğitim Programlarına Etkisi. Felsefe ve Sosyal Bilimler. Felsefe ve Sosyal Bilimler Sempozyumu Bildirileri. Muğla Üniversitesi. 2006;405-413.

17. Senemoğlu N. Gelişim, Öğrenme ve Öğretim: Kuramdan Uygulamaya. 24. Baskı. Ankara: Yargı Yayınları;2015.

18. Akman Y, Erden M. Gelişim Öğrenme Öğretme Eğitim Psikolojisi. 16. Baskı. Ankara: Arkadaş Yayınevi;2007.

19. Şehrinaz P. Farklı kuşaklardan hemşirelerle çalışmak ve hemşireleri yönetmek için ipuçları. Sağlık ve Hemşirelik Yönetimi Dergisi. 2018;1(5):48-56.

20. Karasu F, Aylaz R. Dadük S. X ve Y Kuşağı: Hemşirelerde meslek dayanışması ile iş doyumu arasındaki ilişki. Sağlık Bilimleri ve Meslekleri Dergisi (HSP). 2017;4(3):180-189.

21. Haydari MS, Kocaman G, Tokat MA. Farklı kuşaklardaki hemşirelerin işten ve meslekten ayrılma niyetleri ile örgütsel ve mesleki bağlllıklarının incelenmesi. Sağhk ve Hemşirelik Yönetimi Dergisi. 2016;3(3):119-131.

22. Taş $\mathrm{YH}$, Kaçar S. X, Y ve $Z$ kuşağı çalışanlarının yönetim tarzları ve bir işletme örneği. Uluslararası Toplum Araştırmaları Dergisi - International Journal of Society Researches. 2019;18(11):643-675.

23. Mücevher M. X ve Y Kuşağının Birbirlerine Karşı Özellik ve Etkileşim Algıları: SDÜ Örneği [yüksek lisans tezi]. Isparta: Süleyman Demirel Üniversitesi Sosyal Bilimler Enstitüsü İşletme Anabilim Dalı,2015.

24. Tekin M. Çalışma Yaşamında Kuşaklar Ve İşe Yönelik Tutumlarının İncelenmesi [yüksek lisans tezi]. Isparta: Süleyman Demirel Üniversitesi Sosyal Bilimler Enstitüsü Çalışma Ekonomisi ve Endüstri İlişkileri Anabilim Dalı,2015. 
25. Güney S. Yönetim ve Organizasyon. 2.Baskı. Ankara: Nobel Yayınevi; 2007.

26. Akdemir A, Konakay G, Demirkaya H. Y kuşağının kariyer algısı, kariyer değişimi ve liderlik tarzı beklentilerinin araştırılması. Ekonomi ve Yönetim Araştırmalar Dergisi. 2013;2(2)11-42.

27. Ay Havva P, Çağlar N. Seçmenin siyasal reklamlara yaklaşımı: şüphecilik bakımından kuşaklar arası bir inceleme. Elektronik Sosyal Bilimler Dergisi. 2019;18(70):943-963.

28. Göksel A, Güneş G. Kuşaklar arası farklılaşma: X ve Y kuşaklarının örgütsel sessizlik davranışı. Gazi Üniversitesi İktisadi ve İdari Bilimler Fakültesi Dergisi. 2017;19(3):807-828.

29. İmamoğlu Olcay E, Karakitapoğlu Aygün Z. 1970'lerden 1990'1ara değerler: Üniversite düzeyinde gözlenen zaman, kuşak ve cinsiyet farklılıkları. Türk Psikoloji Dergisi. 1999;14(44):1-22.

30. Koç S, Bardak A, Yılmaz K. Hemşirelik son sınıf öğrencilerinin iş yerinden beklentilerinin belirlenmesi. Hemşirelikte Eğitim ve Araştırma Dergisi. 2014;11(3):43-50.

31. Konakay G. Y Kuşağı değerlerinin kariyer tercihleri açısından incelenmesi. Girişimcilik ve Kalkınma Dergisi. 2018;13(1):79-92.

32. Kuyucu M. Y Kuşağı ve Facebook: Y Kuşağının Facebook kullanım alışkanlıkları üzerine bir inceleme. Elektronik Sosyal Bilimler Dergisi. 2014;13(4950):55-83.

33. Türeli N, Coşkun H. Y Kuşağı üniversite öğrencilerinin girişimcilik yatkınlı̆̆ı: bölümlerarası karşılaştırma. Süleyman Demirel Üniversitesi Sosyal Bilimler Enstitüsü Dergisi. 2018;2(31):326-357.

34. Yüksekbilgili Z, Hatipoğlu Z. Kuşaklara göre örgütsel adalet algısı. Gaziantep University Journal of Social Sciences. 2015;14(2):403-412. 